\title{
PENGARUH INKLUSI KEUANGAN TERHADAP STABILITAS SISTEM KEUANGAN (STUDI KASUS : SELECTED ASIA DEVELOPING COUNTRIES TAHUN 2011-2016)
}

\author{
Yudha Prakasa Hardiyanto ${ }^{1}$, Fitrie Arianti $^{2}$ \\ Universitas Diponegoro \\ Yudhaprakasa.prakasa@gmail.com
}

\begin{abstract}
This research aims to analyse the financial inclusion relationship to financial system stability in developing countries in Asia. The data used in this study are panel data, a combination of time series data from 2011-2016 and cross section of seven developing countries in Asia, namely Bangladesh, Indonesia, India, Malaysia, Pakistan, Thailand and Turkey. This research was conducted with quantitative methods. Quantitative method is done by tobit regression estimation technique The use of tobit regeresi estimation technique is used because the dependent variable is AFSI in a certain range or censored. The result of this study indicate that financial inclussion has a negative and insgignificant influence on financial system stability in selected Asia developing countries. In addition, other variables that a significant effect on financial system stability are the ratio of current assets to deposits and short-term funding, non foreign direct invesment and private credit ratio, significant influence on teh stability of the country's financial system.
\end{abstract}

Keywords: financial inclusion, AFSI, Tobit regresion, developing country in Asia

\section{PENDAHULUAN}

Sejak tahun 2000-an konsep inklusi keuangan telah mendapat perhatian dari banyak negara di dunia, karena menurut (Shimi, 2010) dalam penelitiannya mengungkapkan bahwa upaya inklusi keuangan memiliki efek positif terhadap upaya pengentasan kemiskinan di sebuah negara. Inklusi keuangan merupakan seluruh upaya untuk meningkatkan akses masyarakat terhadap jasa-jasa keuangan dengan cara menghilangkan segala bentuk hambatan baik yang bersifat harga maupun non harga ( Bank Indonesia, 2014). 
Peningkatan inklusi keuangan di Asia dilakukan dengan fokus peningkatan akses lebih kepada masyarakat yang belum menikmati jasa-jasa lembaga keuangan formal dikarenakan terdapat hambatan untuk mengaksesnya (Dienillah dan Anggraeni, 2015). Kunt et al (2008) menjelaskan bahwa, hambatan terhadap akses perbankan dapat disebabkan oleh model bisnis bank itu sendiri, posisi pasar, tingkat kompetisi yang dihadapi, kondisi makroekonomi, serta perjanjian dan peraturan yang dijalankan. Upaya peningkatan inklusi keuangan di Asia telah menunjukkan hasil yang cukup baik seperti yang ditunjukan pada Gambar 1

\section{Gambar 1 Jumlah Rekening Deposit di Bank Komersial per 1.000 Populasi Dewasa 2006-2017}

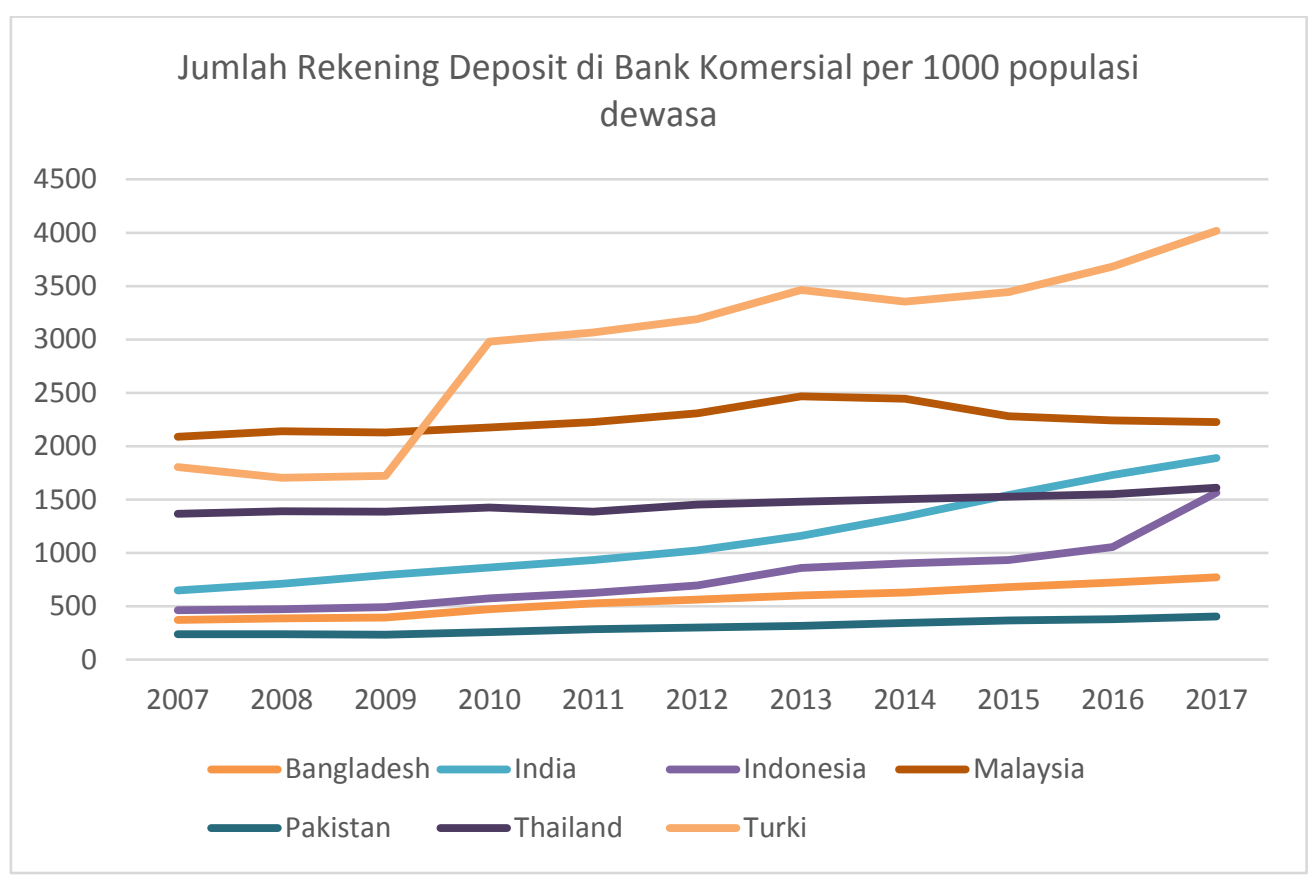

Sumber : IMF, Financial Acccess Survey 2018

Gambar 1.1 menunjukan bahwa setiap tahun secara rata-rata jumlah rekening deposit di bank komersial di 7 negara berkembang Asia diatas mengalami kenaikan. Dari tahun 2007-2017 ketujuh negara diatas mengalami rata-rata kenaikan mencapai 48.23\%. Selama 11 tahun dari 2007-2017, Indonesia memiliki pertumbuhan jumlah rekening deposit di bank komersial tertinggi mencapai angka 70,42\% ; lalu diposisi kedua pertumbuhan tertinggi ditempati oleh India dengan pertumbuhan sebesar $65,69 \%$; posisi ketiga pertumbuhan tertinggi adalah Turki dengan pertumbuhan sebesar 55,09\%. Sedangkan Bangladesh, Pakistan dan Thailand secara berurutan berada di posisi keempat, kelima dan keenam dengan masing-masing pertumbuhan sebesar $51,79 \%$; 41,42\% dan 15,16\%. Dan posisi terakhir adalah Malaysia dengan pertumbuhan sebesar $6,25 \%$. 
Peningkatan inklusi keuangan dilakukan untuk menurunkan angka kemiskinan, pemerataan hasil pembangunan atau pertumbuhan dan peningkatan stabilitas sistem keuangan. Secara teoritis, peningkatan inklusi keuangan akan meningkatan stabilitas sistem keuangan. Tetapi dalam temuan empiris dari penelitianpenelitian sebelumnya menunjukan hasil yang berbeda-beda. Dari penelitan-penelitian terdahulu diketahui bahwa inklusi keuangan memiliki dampak positif dan negatif terhadap stabilitas sistem keuangan. Dalam penelitiannya Khan (2011) mengungkapkan dampak positif dan negatif inklusi keuangan terhadap stabilitas sistem keuangan. Dampak positifnya adalah inklusi keuangan dapat meningkatkan diversifikasi aset perbankan, meningkatkan jumlah penabung sehingga meningkatkan stabilitas basis tabungan, mengurangi resiko prosiklikkal, serta meningkatkan transmisi kebijakan moneter. Sedangkan dampak negatif inklusi keuangan terhadap stabilitas sistem keuangan adalah dapat menurunkan standar kredit dikarenakan lembaga keuangan berusaha menjangkau kalangan masyarakat rendah yang unbankable dengan menurunkan syarat-syarat pinjaman, selain itu dapat meningkatkan risiko reputasi bank dikarenakan guna meningkatkan fasilitas jasa-jasa keuangan beberapa negara yang menurunkan standar pendirian suatu lembaga keuangan untuk daerah pedesaan, serta dapat menyebabkan instabilitas dikarenakan regulasi yang tidak matang dan mencukupi dari lembaga microfinance.

Dalam penelitian lain yang dilakukan oleh Kunt et al (2008) didapatkan bahwa dengan meningkatnya inklusi keuangan dapat meningkatkan diversifikasi deposito bank, dengan meningkatnya diversifikasi aset di masyarakat akan meningkatkan ketahanan sistem keuangan dari guncangan dalam arti lain meningkatkan stabilitas sistem keuangan. Hal ini terjadi karena nasabah dengan nilai deposito tinggi cenderung akan lebih cepat menarik uangnya dari bank saat terjadi guncangan, dibanding dengan nasabah yang memiliki nilai deposito lebih rendah (Huang dan Ratnovski 2011).

Di penelitian-penelitian terdahulu stabilitas sistem keuangan diproksikan dengan Non Performing Loan (NPL) dan Bank Z Score. Dimana didalam penelitian ini NPL dan BZS merupakan salah satu indikator yang menyusun indeks stabilitas sistem keuangan. Gambar 2 menunjukan bahwa negara dengan tingkat NPL tertinggi pada tahun 2011-2016 adalah Pakistan pada tahun 2011 dengan NPL sebesar 16.21\% sedangkan negara dengan tingkat NPL terendah adalah Malaysia pada tahun 2016 dengan nilai NPL sebesar $1.61 \%$.

Pada tahun 2011-2012 NPL Pakistan sangat tinggi jika dibandingkan dengan keenam negara lainnya, hal ini disebabkan karena pada tahun 2011-2012 banyak bank di Pakistan yang menyalurkan kredit secara besar-besaran. Tetapi walaupun nilai NPL nya tinggi, setiap tahunnya menunjukan tren yang menurun. Tren menurun nilai NPL Pakistan diakibatkan karena semakin semakin menurunnya NPL di semua sektor di negara tersebut. Menurunnya NPL semua sektor di Pakistan disebabkan oleh menurun dan stabilnya suku bunga acuan di Pakistan. Berikut adalah kondisi NPL di tujuh negara berkembang Asia yang dipilih : 
Gambar 2 Perkembangan NPL

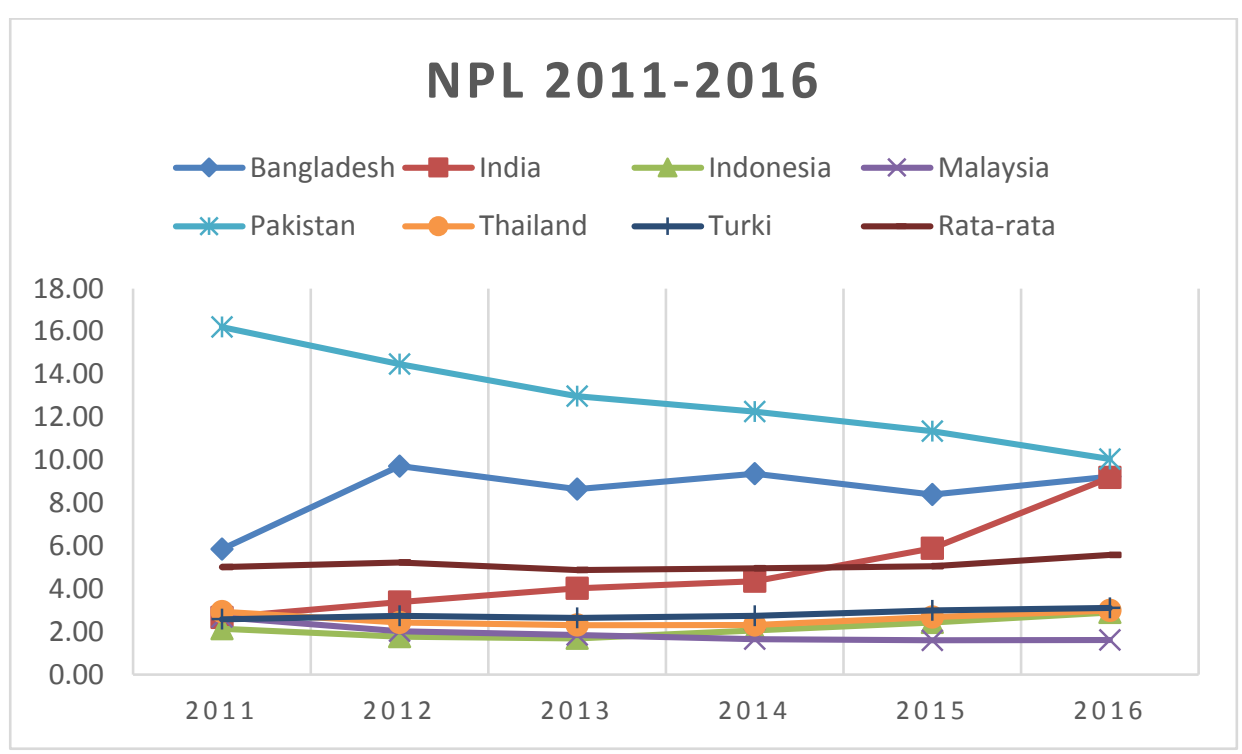

Sumber : World Bank Database (2018)

Pada tahun 2011-2014 hanya terdapat dua negara yang memiliki nilai NPL diatas rata-rata NPL di ketujuh negara tersebut yaitu Pakistan dan Bangladesh. Tetapi setelah tahun 2014-2016 ada tiga negara yang memiliki NPL diatas rata-rata yaitu Bangladesh, Pakistan dan India. Peningkatan NPL di India disebabkan karena meningkatnya NPL di sektor pertanian akibat musim kemarau yang panjang sehingga menyebabkan terjadinya gagal panen di sektor pertanian.

Berbeda dengan penelitian lainnya, Dupas et al (2012) dalam penelitiannya menemukan bahwa meningkatnya inklusi keuangan di Kenya tidak menyebabkan meningkatnya stabilitas sistem keuangan di negara tersebut. Hal ini dikarenakan tidak diikuti dengan penurunan biaya pinjaman bagi masyarakat yang memiliki pendapatan menengah bawah dan tidak diikuti dengan peningkatan kualitas layanan sehingga menyebabkan kurangnya kepercayaan masyarakat terhadap lembaga keuangan. Sedangkan menurut Khan (2011) dalam penelitiannya di tujuh negara berpendapatan menengah dimana menurut World Bank negara berpendapatan menengah masuk kategori negara berkembang, menunjukan fakta bahwa peningkatan inklusi keuangan di tujuh negara tersebut memiliki peluang yang dapat memperkuat stabilitas sistem keuangan dan berpotensi juga menyebabkan instabilitas dalam sistem keuangan di tujuh negara tersebut. Sehingga diperlukan penelitian lebih lanjut untuk semakin mengetahui pengaruh inklusi keuangan terhadap stabilitas sistem keuangan di negara berkembang. 


\section{TINJAUAN PUSTAKA}

\section{Konseptual Stabilitas Sistem Keuangan}

Ada banyak definisi mengenai konsep stabilitas sistem keuangan. Natolyevna dan Ramilevna (2013) mengonseptualisasikan stabilitas keuangan sebagai situasi di mana sistem keuangan, yang terdiri dari pasar keuangan, perantara keuangan dan infrastruktur pasar, mampu menahan guncangan keuangan yang cukup untuk mengacaukan perekonomian. Definisi ini menyiratkan bahwa stabilitas keuangan sangat terkait dengan pengurangan risiko dan ketahanan terhadap guncangan. Sedangkan menurut Bank Indonesia (2007) Sistem keuangan yang stabil adalah sistem keuangan yang kuat dan tahan terhadap berbagai gangguan ekonomi sehingga tetap mampu melakukan fungsi intermediasi, melaksanakan pembayaran dan menyebar risiko secara baik. Tetapi menurut Asian Development Bank Institute belum ada ukuran baku atau kesepakatan internasional tentang pengertian stabilitas sistem keuangan.

Instabilitas sistem keuangan dapat disebabkan oleh faktor struktural maupun perilaku pelaku pasar. Faktor tersebut dapat berasal dari dalam negeri maupun yang berasal dari luar negeri. Dalam penelitian Dienillah et al (2016) sistem keuangan dapat dipengaruhi oleh sektor lain, sektor tersebut adalah :

1. Sektor Ekonomi Riil, dari sektor ekonomi riil ada empat variabel yang mampu memengaruhi stabilitas sistem keuangan yaitu pertumbuhan ekonomi, besaran pajak pemerintah, indeks harga minyak dunia, dan inflasi dalam negeri.

2. Sektor Korporasi, dari sektor korporasi terdapat empat variabel yang mampu memengaruhi stabilitas sistem keuangan. Variabel-variabel tersebut adalah rasio kredit per equity, pengeluaran untuk bunga dan biaya pokok, rasio net foreign exchage exposure terhadap equity, dan kegagalan korporasi.

3. Sektor Rumah Tangga, dari sektor rumah tangga terdapat lima variabel yang mampu memengaruhi stabilitas sistem keuangan. Kelima variabel tersebut yaitu aset yang dimiliki rumah tangga, kredit yang dilakukan rumah tangga, pendapatan rumah tangga, besarnya konsumsi yang dilakukan rumah tangga, serta jasa kredit rumah tangga dan pembayaran pokok.

4. Sektor Eksternal, dari sektor ekternal terdapat delapan variabel yang mampu memengaruhi stabilitas sistem keuangan. Kedelapan variabel tersebut yaitu nilai tukar riil, cadangan nilai tukar, neraca berjalan, arus modal, rasio batas waktu pinjaman terhadap ketidakcocokan mata uang, inflasi global, GDP global, iklim ekonomi global.

5. Sektor Keuangan, dari sektor keuangan terdapat duabelas variabel yang mampu memengaruhi stabilitas sistem keuangan. Keduabelas variabel tersebut yaitu aggregat moneter (tabungan, transaksi, total kredit), jumlah uang beredar, rasio total kredit domestik terhadap GDP, perbedaan suku bunga, profitabilitas perbankan (ROA dan ROE), suku 
bunga riil, risiko sektor perbankan (non-performing loan), kecukupan modal, likuiditas, peringkat kredit perbankan, Bank Z-Score, dan konsentrasi perbankan.

6. Sektor Pasar Keuangan, dari sektor pasar keuangan terdapat lima variabel yang mampu memengaruhi stabilitas sistem keuangan. Kelima variabel tersebut yaitu perubahan pada indeks saham, sebaran obligasi korporasi, kapitalisasi pasar, likuiditas pasar, volatilitas dan harga perumahan.

\section{Konseptual Inklusi Keuangan}

Menurut Nugroho dan Purwanti (2017) istilah financial inclusion atau keuangan inklusif menjadi tren setelah terjadinya krisis 2008. Hal ini terjadi karena pada krisis 2008 kelompok in the bottom of the pyramid (pendapatan rendah dan tidak teratur, tinggal di daerah terpencil, orang cacat, buruh yang tidak mempunyai dokumen identitas legal, dan masyarakat pinggiran) yang umumnya unbankable yang tercatat sangat tinggi di luar negara maju mendapatkan dampak yang luar biasa. Kemunculan pertama kali financial inclusion berasal dari financial exclusion atau pengeculian keuangan. Salah satu definisi awal oleh Leyshon dan Thrift (1995) mendefinisikan pengecualian keuangan merujuk pada proses-proses yang berfungsi untuk mencegah kelompok sosial dan individu tertentu untuk mendapatkan akses ke sistem keuangan formal. Menurut Sinclair (2001), pengecualian keuangan berarti ketidakmampuan untuk mengakses layanan keuangan yang diperlukan dalam bentuk yang sesuai. Pengecualian ini terjadi kepada golongan masyarakat bawah, pengecualian ini terjadi karena tingkat penghasilan yang rendah, permasalahan sosial, angka melek huruf yang rendah, infrastruktur yang tidak memadai di daeraah terpencil, prosedur kredit yang tidak mudah, produk yang ditawarkan lemabaga keuangan tidak sesuai dengan kebutuhan masyarakat golongan ini.

Inklusi keuangan telah menjadi perhatian banyak negara di dunia, walaupun tidak ada definisi baku yang menjadi kesepakatan internasional. Inklusi keuangan merupakan seluruh upaya untuk meningkatkan akses masyarakat terhadap jasa-jasa keuangan dengan cara menghilangkan segala bentuk hambatan baik yang bersifat harga maupun non harga ( Bank Indonesia 2014). Global Financial Development Report (2014) mendefinisikan inklusi keuangan sebagai suatu keadaan dimana mayoritas individu dapat memanfaatkan jasa keuangan yang tersedia serta meminimalisir adanya kelompok individu yang belum sadar akan manfaat akses keuangan melalui akses keuangan yang telah tersedia tanpa biaya tinggi. Sedangkan menurut Hannig dan Jansen (2010) inklusi keuangan adalah upaya untuk memasukan masyarakat unbankable ke dalam sistem keuangan formal sehingga memiliki kesempatan untuk menikmati jasa-jasa lembaga keuangan seperti tabungan, pembayaran, serta transfer. Khan (2011), menggambarkan inklusi keuangan sebagai tindakan yang mencoba untuk memastikan, pertama-tama, akses ke sistem formal dan kemudian menyediakan fasilitas kredit yang tepat waktu dan memadai untuk para pemohon jasa keuangan termasuk orang-orang yang lebih lemah dan kurang beruntung di negara itu. 


\section{Penelitian Terdahulu}

Menggunakan data tahun 2005-2011 Morgan dan Pontines (2014) menyatakan bahwa peningkatan pinjaman kepada UKM dalam total pinjaman bank membantu stabilitas keuangan, terutama oleh penurunan NPL dan kemungkinan gagal bayar yang lebih rendah oleh lembaga keuangan. Hal ini menunjukkan bahwa langkah-langkah kebijakan untuk meningkatkan inklusi keuangan, setidaknya oleh UKM, akan memiliki efek samping berkontribusi terhadap stabilitas keuangan juga. Morgan dan Pontines (2014) juga menemukan bahwa PDB per kapita yang lebih tinggi cenderung meningkatkan stabilitas keuangan, sementara rasio kredit bank swasta yang lebih tinggi terhadap PDB mengurangi stabilitas keuangan.

Hannig dan Jansen (2010) berpendapat bahwa dimasukkannya orang-orang berpenghasilan rendah dan kurang beruntung dalam sistem keuangan akan menyebabkan peningkatan basis kredit dan deposito. Dengan begitu kapasitas rumah tangga miskin dalam mengelola kerentanan keuangan yang diakibatkan oleh dampak buruk krisis, mendiversifikasi basis pendanaan dari lembaga keuangan yang dapat mengurangi guncangan ketika terjadi krisis global, meningkatkan ketahanan ekonomi dengan mempercepat pertumbuhan, memfasilitasi diversifikasi, dan mengurangi kemiskinan.

Dalam penelitiannya tahun 2011 Khan mendapatkan hasil yang menyebutkan bahwa inklusi keuangan memiliki hubungan positif dan negatif teradap stabilitas sistem keuangan. Khan (2011) menjabarkan tiga pendekatan inti di mana inklusi keuangan dapat memiliki pengaruh positif pada stabilitas sistem keuangan. Pertama, dengan meningkatkan jumlah kredit untuk UKM, bank dapat mendiversifikasi portofolio investasi mereka yang pada gilirannya akan mengurangi resiko keseluruhan bank. Kedua, inklusi keuangan yang lebih besar berarti lebih banyak penabung kecil berpartisipasi dalam sistem keuangan. Ketiga, inklusi keuangan yang lebih tinggi mungkin mencerminkan kebijakan moneter yang lebih baik melalui mana tujuan stabilitas keuangan dapat dicapai. Sedangkan dampak negatifnya adalah karena inklusi keuangan dapat menurunan standar kredit dikarenakan lembaga keuangan berusaha menjangkau kalangan masyarakat bawah yang unbankable dengan menurunkan syarat-syarat pinjaman, kedua dapat meningkatkan risiko reputasi bank dikarenakan guna meningkatkan fasilitas jasa-jasa keuangan beberapa negara yang menurunkan standar pendirian suatu lembaga keuangan untuk daerah pedesaan, serta dapat menyebabkan instabilitas dikarenakan regulasi yang tidak matang dan mencukupi dari lembaga Microfinance.

Sedangkan meurut Dienillah dan Anggraeni (2015) dalam penelitiannya menyimpulkan bahwa inklusi keuangan memiliki pengaruh positif terhadap stabilitas sistem keuangan di beberapa negara Asia yang ditelitinya. Ada beberapa negara di Asia seperti Indonesia, India dan Bangladesh yang harus meningkatkan GDP perkapitanya untuk meningkatkan stabilitas sistem keuangan di negaranya. Sedangkan khusus di India hambatan untuk mengakses fasilitas institusi keuangan formalmasih cukup banyak sehingga inklusi keuangannya masih rendah.

\section{METODE PENELITIAN}

\section{Jenis dan Sumber Data}

Jenis data yang digunakan dalam penelitian ini adalah data panel, yaitu gabungan data cross section dan time series. Data cross section yang digunakan dalam 
penelitian ini adalah tujuh negara berkembang di Asia yang dipilih. Dalam penelitian ini untuk menilai negara berkembang digunakan tiga kriteria yaitu pendapatan perkapita, indeks pembangunan manusia dan angka pertumbuhan penduduk. Data time series tahunan periode 2011-2016. Data yang digunakan dalam penelitian adalah jenis data sekunder yang diperoleh dari World Bank, International Monetary Fund (IMF) database, Chinn-Ito database, Federal Reserve Economic Database (FRED),CEIC database, dan Cesifo database. Selain itu untuk menambah kepustakaan, penulis menggunakan literatur tambahan dari buku, jurnal dan penelitian terdahulu lainnya. Pegolahan data dalam penelitian ini dilakukan dengan bantuan software Ms. Excel 2010 dan Stata 14.

Tabel 1 Data dan Sumber data

\begin{tabular}{|c|c|c|c|}
\hline NO. & DATA atau Indikator & Satuan & Sumber \\
\hline \multicolumn{4}{|c|}{ Financial Development Index (FDI) } \\
\hline 1. & Kapitalisasi Pasar/ GDP & $\%$ & World Bank \\
\hline 2. & National Currency Credit /GDP & $\%$ & World Bank \\
\hline 3. & Konsentrasi Perbankan & $\%$ & FRED \\
\hline \multicolumn{4}{|c|}{ Financial Vulnerability Index $(F V I)$} \\
\hline 4. & Inflasi , consumer price & $\%$ & World Bank \\
\hline 5. & $\begin{array}{l}\text { General Balance, Surplus or Deficit } \\
\text { /GDP }\end{array}$ & $\%$ & CEIC \\
\hline 6. & Current Account /GDP & $\%$ & World Bank \\
\hline 7. & Real Effective Exchange Rate (change) & $\%$ & FRED \\
\hline 8. & Non Goverment Credit/total credit & $\%$ & World Bank \\
\hline 9. & Pinjaman/Deposit & $\%$ & FRED \\
\hline 10. & Deposit/JUB(M2) & Indeks & FAS-IMF \\
\hline \multicolumn{4}{|c|}{ Financial Soudness Index (FSI) } \\
\hline 11. & Presentase kredit macet/ total kredit & $\%$ & World Bank \\
\hline 12. & Bank Capital to total aset & $\%$ & World Bank \\
\hline 13. & Bank Return on Asset (ROA) & $\%$ & FRED \\
\hline 14. & Bank Z Score & $\%$ & FRED \\
\hline \multicolumn{4}{|c|}{ World Economic Climate Index $($ WECI) } \\
\hline 15. & Tingkat inflasi dunia, consumer price & $\%$ & FRED \\
\hline 16. & Pertumbuhan Ekonomi Dunia & $\%$ & World Bank \\
\hline 17. & Iklim Ekonomi Dunia & Indeks & Cesifo \\
\hline \multicolumn{4}{|c|}{ Inclusion Financial Index (IFI) } \\
\hline 18. & $\begin{array}{l}\text { Jumlah rekening deposit di bank per } \\
1.000 \text { populasidewasa }\end{array}$ & Unit & FAS-IMF \\
\hline 19. & $\begin{array}{l}\text { Jumlah cabang dari bank per } 100.000 \\
\text { populasi }\end{array}$ & Unit & FAS-IMF \\
\hline 20. & $\begin{array}{l}\text { Proporsi kredit dan tabungan terhadap } \\
\text { GDP }\end{array}$ & $\%$ & FAS-IMF \\
\hline
\end{tabular}




\begin{tabular}{|c|l|c|c|}
\hline NO. & \multicolumn{1}{|c|}{ DATA atau Indikator } & Satuan & Sumber \\
\hline 21. & Pendapatan Perkapita & USD/orang & World Bank \\
\hline 22. & $\begin{array}{l}\text { Kredit Swasta di perbankan terhadap } \\
\text { GDP }\end{array}$ & $\%$ & World Bank \\
\hline 23. & $\begin{array}{l}\text { Rasio Aset lancar terhadap desposito } \\
\text { dan pendanaan jangka pendek }\end{array}$ & $\%$ & FAS IMF \\
\hline 23. & Keterbukaan Keuangan & Indeks & $\begin{array}{c}\text { Chin-ito } \\
\text { database }\end{array}$ \\
\hline 24. & Non Foreign Direct Invesment (NFDI) & USD & World Bank \\
\hline
\end{tabular}

\section{Perhitungan Agregate Financial Stability Index (AFSI)}

Menurut Albulescu dan Goyeau (2010) untuk melakukan perhitungan AFSI/ indeks stabilitas sistem keungan, hal pertama yang dilakukan adalah pengelompokan indikator- indikator kedalam empat sub indeks yang ada yaitu subindeks pembangunan keuangan, subindeks kerentanan keuangan, subindeks kesehatan institusi keuangan dan subindeks iklim ekonomi dunia. Setelah itu dilakukan normalisasi indikator dengan normalisasi empiris, setelah dinormalisai nilai indikator akan berada direntang 0-1, dimana 0 adalah nilai terendah atau terburuk sedangkan 1 adalah nilai tertinggi atau terbaik. Sehingga rumus normalisasi untuk indikator yang memiliki dampak positif terhadap stabilitas sistem keuangan adalah sebagi berikut:

$$
\mathrm{I}_{\mathrm{it}} \mathrm{n}=\frac{\mathrm{Iit}-\operatorname{Min}(\mathrm{Ii})}{\operatorname{Max}(I i)-\operatorname{Min}(I i)}
$$

Sedangkan untuk normalisasi indikator yang melemahkan stabilitas sistem keuangan seperti inflasi domestik, inflasi dunia dan NPL berikut rumus normalisasinya:

Dimana :

$$
\mathrm{I}_{\mathrm{it}} \mathrm{n}=1-\frac{\mathrm{Iit}-\operatorname{Min}(\mathrm{Ii})}{\operatorname{Max}(I i)-\operatorname{Min}(I i)}
$$

Iitn : nilai indikator yang telah dinormalisasi

Iit $\quad$ : nilai indikator individu i pada waktu ke $\mathrm{t}$

Min (Ii) : nilai indikator terendah individu i selama periode pengamatan

$\operatorname{Max}(\mathrm{Ii}) \quad$ : nilai indikator tertinggi individu i selama periode pengamatan

Untuk membangun Agregate Financial Stability Index (AFSI) atau indeks stabilitas keuangan dilakukan pembobotan terhadap masing-masing sub indeks berdasarkan jumlah indikatornya. Setelah itu dijumlahnya untuk membangun AFSI, sehingga perhitungannya sebagai berikut :

$$
\mathrm{AFSI}=\frac{3 F D I t}{17}+\frac{7 F V I t}{17}+\frac{4 F S I t}{17}+\frac{3 W E C I t}{17}
$$

Sehingga pembobotannya adalah : 


$$
\mathrm{AFSI}=0.177 \mathrm{FDI}+0.411 \mathrm{FVI}+0.235 \mathrm{FSI}+0.177 \mathrm{WECI}
$$

\section{Perhitungan Indeks Inklusi Keuangan (IFI)}

Perhitungan indeks inklusi keuangan yang dilakukan dalam penelitian ini menggunakan metode yang yang dikembangkan Sarma (2012). Sebelum melakukan perhitungan indeks inklusi keuangan hal yang dilakukan pertama ada dengan melakukan normalisasi dengan rumus sebagai berikut :

$$
\mathrm{di}=\mathrm{wi} \frac{A i-M i n i}{\operatorname{Mak} i-\operatorname{Min} i}
$$

Dimana :

$\mathrm{di}=$ nilai indikator yang telah dinormalisasi untuk dimensi $\mathrm{i}$

wi $=$ bobot untuk dimensi i , $0 \leq \mathrm{wi} \leq 1$, dalam kasus ini dasumsikan 1

$\mathrm{Ai}=$ nilai terkini dari indikator $\mathrm{i}$

Min i = nilai minimum atau batas bawah dari indikator i

Mak $\mathrm{i}=$ nilai maksimum atau batas atas dari indikator $\mathrm{i}$

Indeks dari inklusi keuangan dari negara i dapat dihitung dengan:

$$
\mathrm{IFI}=\frac{1}{2}\left(\frac{\sqrt{a^{2}+k^{2}+u^{2}}}{\sqrt{3}}+\left(1-\frac{\sqrt{(1-a)^{2}+(1-k)^{2}+(1-u)^{2}}}{\sqrt{3}}\right)\right)
$$

Dimana :

$\mathrm{a}=$ akses keuangan

$\mathrm{k}=$ Ketersediaan jasa keuangan

$\mathrm{u}=$ kegunaan

Hasil dari perhitungan IFI dalam penelitian ini merupakan perbandingan relatif antar negara. Karena penentuan batas atas dan batas bawah hanya dari distribusi data yang diobservasi maka nilai indeks inklusi keuangan mungkin saja berbeda jika jumlah negara dan tahun yang diobservasi juga ditambah.

\section{Metode Analisis}

\section{Permodelan Regresi Tobit}

Dalam penelitian ini alat analisis yang digunakan adalah regresi tobit. Model tobit merupakan perluasan dari model probit yang pertama kali dikembangkan oleh James Tobin. Dalam penelitian Dienillah et al (2016) disebutkan bahwa model regresi tobit disebut juga regresi tersensor hal ini disebabkan karena variabel dependen dalam regresi tobit memiliki nilai yang berada dalam rentang tertentu. Penaksiran parameter dalam regresi model tobit menggunakan metode Maximum Likehood Estimation (MLE). Sehingga secara umum model tobit dapat ditulis sebagai berikut : 


$$
\begin{aligned}
& Y_{t}^{*}=X_{t}^{\prime} \beta \mathrm{o}+\varepsilon_{\mathrm{t}}, \mathrm{t}=1,2, \ldots \ldots \ldots . . \mathrm{n} \\
& \mathrm{Y}_{\mathrm{t}}=\left\{\begin{array}{l}
Y_{t}^{*} \text { jika } Y_{t}^{*}>c \\
c \text { jika } Y_{t}^{*} \leq c
\end{array}\right.
\end{aligned}
$$

Dimana :

$Y_{t}^{*}=$ Variabel tak bebas

$X_{t}^{\prime}=$ Variabel bebas

$\beta \mathrm{o}=$ koefisien

$\varepsilon_{\mathrm{t}}=$ Residual

Variabel dependen yang digunakan dalam penelitian ini adalah AFSI atau indeks stabilitas sistem keuangan yang memproksikan stabilitas sistem keuangan.Variabel independennya yaitu IFI atau indeks inklusi keuangan sebagai proksi inklusi keuangan (financial inclusion), LN GDP perkapita, rasio kredit swasta dari deposito bank dan lembaga keuangan lain terhadap GDP, dan indeks keterbukaan keuangan (financial openness). Sehingga persamaan regresi tobitnya yaitu:

$$
\mathrm{AFSI}_{\mathrm{i}, \mathrm{t}}=\mathrm{b}_{1}+\mathrm{b}_{2} \mathrm{IFI}_{\mathrm{t}, \mathrm{t}}+\mathrm{b}_{3} \mathrm{LNGDPP}_{\mathrm{i}, \mathrm{t}}+\mathrm{b}_{4} \mathrm{CGDP}_{\mathrm{i}, \mathrm{t}}+\mathrm{b}_{5} \mathrm{LIQ}_{\mathrm{i}, \mathrm{t}}+\mathrm{b}_{6} \mathrm{OF}_{\mathrm{i}, \mathrm{t}}+\mathrm{b}_{7} \mathrm{NFDI}+\mathrm{e}_{\mathrm{i}, \mathrm{t}}
$$

Dimana :

AFSI $\quad$ :Proksi untuk stabilitas sistem keuangan yang diproksikan oleh Agregate Financial Stability Index (AFSI) untuk negara i tahun ke t; AFSI dalam satuan indeks

IFI $_{\mathrm{i}, \mathrm{t}} \quad$ : Proksi untuk inklusi keuangan yang diwakili oleh Inclusion Financial Index (IFI) untuk negara i tahun ke $\mathrm{t}$

LGDPP $_{\mathrm{i}, \mathrm{t}} \quad$ :Logaritma Natural GDP perkapita untuk negara i tahun ke $\mathrm{t}(\%)$

$\mathrm{CGDP}_{\mathrm{i}, \mathrm{t}} \quad$ : Rasio kredit swasta dari deposito bank dan lembaga keuangan lain terhadap GDP untuk negara i tahun ke $\mathrm{t}(\%)$.

$\mathrm{LIQ}_{\mathrm{i}, \mathrm{t}} \quad$ : Rasio aset lancar terhadap deposito dan pembiayaan jangka pendek untuk negara i tahun ke $\mathrm{t}(\%)$.

$\mathrm{OPNS}_{\mathrm{i}, \mathrm{t}} \quad$ : Indeks keterbukaan keuangan (financial openness) untuk negara i tahun ke t (Indeks).

NFDI $i_{i, t} \quad$ :Non Foreign Direct Investment untuk negari i tahun ke $\mathrm{t}$ (Indeks). 


\section{HASIL DAN PEMBAHASAN}

\section{Gambaran Umum Agregate Financial Stability Index (AFSI) Tujuh Negara Berkembang di Asia yang dipilih}

Agregate Financial Stability Index (AFSI) diukur dari agregasi empat sub indeks keuangan yaitu sub indeks pembangunan keuangan (FDI), sub indeks kerentanan keuangan (FVI), sub indeks kesehatan keuangan (FSI) dan sub indeks iklim ekonomi dunia (WECI) yang telah dinormalisasi. Sehingga setelah dilakukan agregasi dan rata-rata selama 2011-2016 didapatkan hasil sebagai berikut:

Tabel 2 Rata-rata Indeks Sistem Keuangan di Tujuh Negara Tahun 2011-2016

\begin{tabular}{|c|c|c|c|c|c|}
\hline & FDI & FVI & FSI & WECI & AFSI \\
\hline Bangladesh & 0.077 & 0.416 & 0.354 & 0.514 & 0.358 \\
\hline India & 0.234 & 0.395 & 0.628 & 0.514 & 0.442 \\
\hline Indonesia & 0.141 & 0.508 & 0.653 & 0.514 & 0.477 \\
\hline Malaysia & 0.658 & 0.595 & 0.784 & 0.514 & 0.635 \\
\hline Pakistan & 0.161 & 0.275 & 0.445 & 0.514 & 0.336 \\
\hline Thailand & 0.585 & 0.653 & 0.543 & 0.514 & 0.589 \\
\hline Turki & 0.169 & 0.495 & 0.624 & 0.514 & 0.470 \\
\hline
\end{tabular}

Sumber : WB, IMF, FRED, CIEC, CESifo data diolah (2018)

Tabel 2 menunjukan bahwa negara dengan tingkat rata-rata AFSI atau indeks stabilitas sistem keuangan terendah adalah Pakistan sedangkan yang tertinggi adalah Malaysia .Penyebab rendahnya indeks stabilitas sistem keuangan di Pakistan karena Pakistan memiliki nilai rata-rata sub indeks FVI terendah dibanding negara lainnya, hal ini disebabkan karena penyaluran kredit non pemerintah dan rasio kredit terhadap deposito yang rendah. Sedangkan Malaysia memiliki indeks stabiltas tinggi karena didukung dengan rata-rata sub indeks FDI dan FSI tertinggi dibanding dengan negara lainnya. Tingginya sub indeks FDI di Malaysia dikarenakan kapitalisasi pasar modal Malaysia yang paling tinggi diantara negara lainnya. Sedangkan tingginya sub indeks FSI di Malaysia dikarenakan Malaysia memiliki nilai NPL yang rendah. Sedangkan untuk Bangladesh memiliki rata-rata sub indeks FDI terendah dibanding dengan negara lain dikarenakan kapitalisasi pasar modal Bangladesh yang rendah bahkan dari tahun 2011-2016 mengalami penururan sebesar 40\% . Tujuh negara berkembang Asia yang dipilih memiliki nilai indeks stabilitas sistem keuangan yang berfluktuatif dari tahun ke tahunnya. 


\section{Gambaran Umum Inklusi Keuangan Tujuh Negara Berkembang di Asia yang dipilih}

IFI (Inclusion Financial Index) atau indeks inklusi keuangan di hitung berdasarkan tiga dimensi yaitu akses lembaga keuangan (a) yang diukur dari indikator jumlah rekening deposito per 1.000 populasi dewasa, ketersedian jasa keuangan $(\mathrm{k})$ yang diukur dengan jumlah cabang bank per 100.000 populasi dewasa dan kegunaan jasa keuangan (u) yang diukur dari jumlah kredit dan deposito terhadap GDP. Tabel 4.4 menunjukan rata-rata IFI dan tiga dimensinya.

Tabel 3. Rata-Rata IFI 2011-2016

\begin{tabular}{|c|c|c|c|c|}
\hline & $\begin{array}{c}\text { Dimensi } \\
\text { Akses (a) }\end{array}$ & $\begin{array}{c}\text { Dimensi } \\
\text { Ketersedia (k) }\end{array}$ & $\begin{array}{c}\text { Dimensi } \\
\text { Kegunaan (u) }\end{array}$ & IFI \\
\hline Bangladesh & 0.213 & 0.099 & 0.230 & 0.132 \\
\hline India & 0.586 & 0.295 & 0.380 & 0.356 \\
\hline Indonesia & 0.521 & 0.165 & 0.058 & 0.362 \\
\hline Malaysia & 0.208 & 0.602 & 0.969 & 0.595 \\
\hline Pakistan & 0.263 & 0.014 & 0.041 & 0.081 \\
\hline Thailand & 0.654 & 0.353 & 0.910 & 0.539 \\
\hline Turki & 0.937 & 0.907 & 0.274 & 0.672 \\
\hline
\end{tabular}

Sumber : FAS IMF Database (2019), data diolah

Dari tabel 3 terlihat bahwa Turki adalah negara dengan tingkat rata-rata inklusi tertinggi dengan nilai 0.672, menurut Sarma (2008) IFI bernilai $\geq 0.6$ berarti digolongkan dalam kelompok negara dengan tingkat inklusi keuangan yang bagus. Sedangkan India, Indonesia, Malaysia, dan Thailand memiliki nilai IFI kurang dari 0.6 tetapi lebih dari 0.3 sehingga digolongkan negara dengan tingkat inklusi keuangan sedang. Dari tujuh negara yang dipilih Bangladesh dan Pakistan memiliki IFI dibawah 0.3 sehingga masuk kedalam kelompok negara dengan tingkat inklusi rendah.

\section{Faktor-Faktor Yang Mempengaruhi Stabilitas Sistem Keuangan}

Untuk menjawab pertanyaan penelitian mengenai faktor-faktor yang mempengaruhi stabilitas sistem keuangan negara berkembang di Asia pada periode 2011-2016. Dengan menggunakan regresi tobit didapat hasil estimasi sebagai berikut :

Tabel 4 menunjukan hasil regresi dari model. Dan hasilnya terlihat bahwa variabel yang mempengaruhi stabilitas sistem keuangan secara nyata adalah rasio kredit swasta terhadap GDP (CPGDP),rasio aset lancar terhadap deposito dan pendanaan jangka pendek (LIQ) serta non foreign direct investment (NFDI). Sedangkan variabel yang tidak berpengaruh nyata terhadap stabiltas sistem keuangan adalah inklusi keuanga (IFI), pertumbuhan pendapatan perkapita (LNGDPP) dan indeks keterbukaan keuangan (OF). 
Tabel 4 Hasil Regresi

\begin{tabular}{|c|c|c|c|}
\hline Variabel & Koefisien & t-Statistik & Prob. \\
\hline C & -0.3724834 & -1.42 & 0.163 \\
\hline IFI & -0.142624 & -0.99 & 0.329 \\
\hline X2LNGDPP & 0.038389 & 1.18 & 0.246 \\
\hline X3CPGDP & 0.00163 & 4.61 & 0.000 \\
\hline X4LIQ & -0.0030334 & 2.23 & 0.032 \\
\hline X5OF & -0.0129021 & -0.46 & 0.650 \\
\hline X6NFDI & 0.191944 & 4.17 & 0.000 \\
\hline
\end{tabular}

Sumber : Output Stata 14

\section{Hubungan Inklusi Keuangan (IFI) terhadap Stabilitas Sistem Keuangan}

Inklusi keuangan terindikasi memiliki hubungan yang negatif dan tidak signifikan pada taraf 5\% terhadap stabilitas sistem keuangan di tujuh negara berkembang Asia yang dipilih. Hal ini dikarenakan dinegara berkembang peningkatan inklusi keuangan tidak dibarengi dengan penurunan biaya pinjaman bagi masyarakat menengah kebawah dan tidak dibarengi dengan peningkatan fasilitas oleh lembaga keuangan formal sehingga masyarakat kurang percaya dengan lembaga keuangan formal (Dupas et al 2012). Selain itu penyebab inklusi berpotensi menyebabkan instabillitas sistem keuangan di negara berkembang diakibatkan oleh penurunan standar syarat-syarat kredit oleh lembaga keuangan untuk kalangan masyarakat yang unbankable, kedua dapat meningkatkan risiko reputasi bank dikarenakan guna meningkatkan fasilitas jasa-jasa keuangan beberapa negara yang menurunkan standar pendirian suatu lembaga keuangan untuk daerah pedesaan, serta dapat menyebabkan instabilitas dikarenakan regulasi yang tidak matang dan mencukupi dari lembaga Microfinance (Khan 2011). Seperti yang terjadi di Indonesia akhir-akhir ini bahwa Otoritas Jasa Keuangan (OJK) menutup lembaga pembiayaan online / microfinance yang terindikasi bodong.

\section{Hubungan Pendapatan Perkapita (GDPP) terhadap Stabilitas Sistem Keuangan}

Pendapatan perkapita (GDPP) terindikasi memiliki hubungan positif dan tidak signifikan pada taraf 5\% terhadap stabilitas sistem keuangan. Ketidak signifikan an ini disebabkan karena masyarakat di negara berkembang mayoritas adalah kelas menengah yang cenderung membelanjakan uangnnya dibanding dengan menempatkan dananya di pasar keuangan atau lemabaga keuangan. Sehingga peningkatan pendapatan tidak memiliki efek yang signifikan terhadap stabilitas keuangan. 


\section{Hubungan Rasio Kredit Swasta terhadap GDP (CPGDP) terhadap Stabilitas Sistem Keuangan}

Variabel rasio kredit swasta terhadap GDP (CPGDP) memiliki hubungan yang positif dan signifikan terhadap stabilitas sistem keuangan pada taraf $5 \%$. Semakin meningkatnya rasio pinjaman swasta menandakan semakin lancarnya fungsi intermediasi sektor perbankan. Saat fungsi intermediasi perbankan semakin lancar akan memperdalam pasar keuangan di sebuah negara. Pendalaman pasar keuangan akan semakin memperkuat sistem keuangan saat terjadi guncangan. Hasil ini sejalan dengan penelitian Lukytawati (2017) yang juga menyebutkan rasio kredit swasta memiliki hubungan postif dengan stabilitas sistem keuangan.Hal ini diperkuat oleh penelitian Dienillah et al (2016) yang menyebut rasio kredit swasta memiliki hubungan positif dan signifikan terhadap stabilitas sistem keuangan. Hal ini dikarenkan peningkatan kredit swasta akan meningkatkan pertumbuhan di sektor riil dan sektor keuangan.

\section{Hubungan Rasio Aset Lancar terhadap Deposito dan Pendanaan Jangka Pendek (LIQ) terhadap Stabilitas Sistem Keuangan}

Variabel rasio aset lancar terhadap deposito dan pendanaan jangka pendek (LIQ) memiliki hubungan yang positif dan signifikan terhadap stabilitas sistem keuangan pada taraf 5\%. Hal ini sejalan dengan penelitian Dienillah dan Anggraeni (2015) yang menyebutkan rasio aset lancar terhadap deposito dan pendanaan jangka pendek memiliki hubungan positif dan signifikan terhadap stabilitas sistem keuangan di negara berkembang. Hal ini dikarenakan peningkatan LIQ akan meningkatkan kemampuan bank dalam menghadapi guncangan sehingga meningkatkan kepercayaan di masyarakat (Morgan dan Pontines 2014).

\section{Hubungan Keterbukaan Keuangan (OF) terhadap Stabilitas Sistem Keuangan}

Variabel keterbukaan keuangan (OF) terindikasi memiliki hubungan negatif tetapi tidak memiliki pengaruh yang nyata terhadap stabilitas sistem keuangan. Hal ini sejalan dengan penelitian yang dilakukan Dienillah dan Anggraeni (2015) yang juga menyimpulkan OF tidak memiliki pengaruh nyata terhadap stabilitas sistem keuangan.

\section{Hubungan Non Foreign Direct Investment (NFDI) terhadap Stabilitas Sistem Keuangan}

Variabel non foreign direct investment (NFDI) memiliki hubungan yang positif dan signifikan terhadap stabilitas sistem keuangan. Hal ini sejalan dengan penelitian Lukytawati (2017) serta Dienillah dan Anggraeni (2015). Hal ini dikarenakan NFDI dapat meningkatkan cadangan devisa di suatu negara. Cadangan devisa yang besar dapat menyerap guncangan yang berasal dari eksternal saat terjadi krisis. Sehingga guncangan yang berasal dari luar negeri tidak akan meyebabkan gangguan dalam sistem keuangan domestik. 


\section{KESIMPULAN}

\section{Simpulan}

Beberapa penelitian sebelumnya menyimpulkan bahwa inklusi keuangan memiliki hubungan yang positif terhadap stabilitas sistem keuangan, tetapi beberapa penelitian lain juga menyimpulkan inklusi keuangan memiliki hubungan yang negatif dengan stabilitas sistem keuangan. Sedangkan penelitian ini menyimpulkan bahwa inklusi keuangan yang diukur dengan variabel indeks inklusi keuangan (IFI) terindikasi memiliki hubungan yang negatif dan tidak signifikan terhadap stabilitas sistem keuangan. Hal ini dikarenakan peningkatan inklusi keuangan di negara berkembang tidak diikuti dengan penurunan biaya pinjaman dan penurunan standar syarat-syarat untuk kredit.

Selain inklusi keuangan, faktor-faktor lain yang berpengaruh signifikan terhadap stabilitas sistem keuangan tujuh negara berkembang Asia yang dipilih tahun 2011-2016 adalah rasio kredit swasta terhadap GDP (CPGDP), rasio aset lancar terhadap deposito dan pendanaan jangka pendek (LIQ), dan non foreign direct invesment (NFDI).

Selain itu penelitian ini menemukan bahwa dari ketujuh negara berkembang Asia yang dipilih satu negara yaitu Turki memiliki tingkat inklusi keuangan dengan kategori tinggi, sedangkan empat negara yaitu India, Indonesia, Malaysia dan Thailand memiliki tingkat inklusi keuangan dengan kategori sedang, lalu untuk dua negara lainnya yaitu Bangladesh dan Pakistan memiliki tingkat inklusi keuangan dalam kategori rendah. Sedangkan dari segi stabilitas sistem keuangan Malaysia adalah negara dengan nilai indeks stabilitas sistem keuangan tertinggi dengan nilai 0.635 , tingginya indeks stabilitas sistem keuangan di Malaysia didukung dengan tingginya kapitalisasi pasar modal Malaysia dan rendahnya angka Non Performing Loan (NPL) di Malaysia .Negara dengan indeks stabilitas sistem keuangan terendah adalah Pakistan dengan nilai indeks sebesar 0.336. Sedangkan untuk negara lainnya yaitu Bangladesh, India, Indonesia, Thailand dan Turki memiliki nilai indeks stabilitas sistem keuangan dalam rentang 0.358-0,589.

\section{Implikasi Kebijakan}

Penelitian ini menemukan bahwa inklusi keuangan berhubungan negatif dan tidak signifikan terhadap stabilitas sistem keuanga. Hal ini diperkuat dengan hasil penelitian Dienillah (2016) yang menyatakan bahwa inklusi keuangan tidak berdampak signifikan terhadap stabilitas sistem keuangan di negara berkembang, tetapi memiliki dampak positif dan signifikan di negara maju. Selain itu hal ini juga di perkuat dengan hasil peneltian Khan (2011) dan Dupas et al (2012) yang menyatakan inklusi keuangan berdampak negatif jika tidak dibarengi dengan penurunan biaya kredit ke masyarakat menengah bawah dan penurunan standar syarat-syarat pengajuan kredit untuk kalangan unbankable serat regulasi yang kurang matang untuk lembaga microfinance. 
Berdasarkan penjabaran diatas dijelaskan faktor-faktor yang meyebabkan inklusi keuangan berdampak negatif terhadap stabilitas sistem keuangan. Sehingga cara untuk mengatasi hal tersebut adalah dengan penurunan biaya kredit untuk masyarakat berpendapatan menengah kebawah, memperketat aturan penyaluran kredit dan pembuatan regulasi yang jelas dan pengawasan yang ketat terhadap pendirian dan pengoprasian lembaga-lembaga microfinance.

Berdasarkan temuan Dienillah et al (2016) didapatkan bahwa NFDI memiliki hubungan yang positif dan signifikan terhadap stabilitas sistem keuangan. Dalam penelitian ini didapatkan hal sama, bahwa NFDI berhubungan positif dan signifikan. Hubungan positif ini dikarenakan NFDI mendorong peningkatan cadangan devisa disuatu negara,sehingga dengan cadangan devisa yang tinggi dapat menyerap shock atau guncangan yang berasal dari luar negeri. Dari penjabaran tersebut maka yang dapat dilakukan pemerintah untuk menarik NFDI lebih banyak adalah dengan menjaga kepercayaan investor melalui keadaan politik, ekonomi dan hukum yang stabil. Dan peningkatan instrumen-istrumen dalam pasar keuangan sehingga menarik investor asing untuk menanamkan modalnya.

\section{DAFTAR PUSTAKA}

Albulescu, C. T., \& Goyeau, D. (2010). Assessing and Forecasting Romanian Financial System's Stability Using an Aggregate Index. Romanian Journal Economic Literatur, 85-90.

Allen, F., Kunt, A. D., Klapper, L., \& Peria, M. (2012). The foundations of financial inclusion: Understanding ownership and use of formal accounts. Journal of Financial Intermediation.

Anatolyevna, M. I., \& Ramilevna, S. L. (2013). Financial Stability Concept: Main Characteristics and Tools. World Applied Sciences Journal , 856-858.

Awanti, E. (2017). Analisis Pengaruh Inklusi Keuangan terhadap Stabilitas Sistem Keuangan Di Negara Berkembang Kawasan Asia Tenggara. Economics Journal of Airlangga University.

Bank Indonesia. (2007). Booklet Stabilitas Sistem Keuangan. Jakarta: Bank Indonesia.

Bank Indonesia. (2014). Booklet Keuangan Inklusif. Jakarta: Bank Indonesia.

CEIC. (2019, Juni 27). Diambil kembali dari CEIC Global Economic Data: https://www.ceicdata.com/id

Dienillah, A. A., \& Anggraeni, L. (2016). Dampak Inklusi Keuangan Terhadap Stabilitas Sistem Keuangan Di Asia. Buletin Ekonomi Moneter dan Perbankan, 409-430. 
Dienillah, A. A., Anggreini, L., \& Sahara. (2016). Impact of Financial Inclusion on Financial Stability Based on Income Group Countries. Bulletin of Monetary Economics and Banking, 429-442.

Dupas, P., Green, S., Keats, A., \& Robinson, J. (2012). Challenges in Banking the Rural Poor Evidence from Kenya's Western Province. National Bureau of Economic Research Working Paper no 17851.

European Central Bank. (2012). What Is FInancial Stability? . Frankfurt: European Central Bank.

Federal Reserve Economic Database (FRED). (2019, Juni 27). FRED Economic Reserch. Diambil kembali dari FRED Economic Reserch: https://fred.stlouisfed.org/

Ghozali, I. (2012). Ekonometrika, Teori, Konsep dan Aplikasi. Semarang: Badan Penerbit Universitas DIponegoro.

Gujarati, D., \& Potter, D. (2012). Dasar-Dasar Ekonometrika. Jakarta: Salemba Empat.

Han, R., \& Melecky, M. (2013). Financial Inclusion for Financial Stability Access to Bank Deposits and the Growth of Deposits in the Global Financial Crisis. Policy Research Working Paper World Development Report.

Hannig, A., \& Jansen, S. (2010). Financial Inclusion and Financial Stability: Current Policy Issues. ADBI Working Paper Series.

Houben, A., Kakes, J., \& Schinasi, G. (2004). Toward a Framework for. IMF Working Paper.

Huang, R., \& Ratnovski, L. (2011). The Dark Side of Bank Wholesale Funding. IMF Working Paper, 1-28.

Ifo Institut. (2019, juni 27). Diambil kembali dari Cesifo Intitut: https://www.ifo.de/

IMF. (2019, Januari 20). Financial Access Survey. Dipetik Desember 28, 2018, dari IMF Data: http://data.imf.org/

International Monetary Fund. (2018). World Economy Outlook 2018. Washington DC: IMF.

Khan, H. (2011). Financial inclusion and financial stability: are they two sides. BIS Paper, 1-12.

Kunt, A., Beck, T., \& Honohan. (2008). Finance for All? Policies and Pitfalls in Expanding Access.

Leyshon, A., \& Thrift, N. (1995). Financial Exclusion and the Shifting Boundaries of the Financial System. Environment and Planning A : Economic and Space, $1150-1156$. 
MacFarlane, I. (1999). The Stability of the. Reserve Bank of Australia Bulletin, 34-42.

Morgan, P., \& Pontines, V. (2014). Financial Stability and Financial Inclusion. ADBI Working Paper Series.

Nugroho, A., \& Purwanti, E. Y. (2017). Determinan Inklusi Keuangan di Indonesia (Global Findex 2014). Jurnal Dinamika Ekonomi Pembangunan.

Sarma, M. (2012). Index of Financial Inclusion - A measure of financial. Berlin Working Papers on Money, Finance, Trade and Development no 07.

Sarma, M., \& Paris, J. (2008). Financial and Development A : Cross Country Analysis . Berlin Working Papers on Money, Finance, Trade and Development.

Shimi, I. (2010, October 28). Financial inclusion - an imperative towards Vision 2030. BIS Review.

Siddik, M. A., \& Kabiraj, S. (2018). Does Financial Inclusion Induce Financial Stability? Evidence from Cross-country Analysis. Australian Acconting, Business, and FInance Journal, 31-46.

Siddik, M., Sun, G., \& Kabiraj, S. (2015). Financial Inclusion and its determinants : a study of Bangladesh. Indian Journal of Finance, 7-9.

Sinclair , S. (2001). Financial Inclusion and Social Financialisation: Britain in a European Contex. International Journal of Sociology and Social Policy, 658676.

(2014). The Mutualy -Supportive Relationship Between Financial Inclusion and Financial Stability. Dhaka: Bangladesh Bank.

Todaro, M., \& Smith, S. (2004). Pembangunan EKonomi di Dunia Ketiga. Jakarta: Erlangga.

United Nations. (2006). Role of microcredit and microfinance in the eradication of poverty. Resolution 61/214 (hal. 1-3). New York: United Nations.

World Bank . (2014). Global FInancial Developmen Report . Washington DC: The World Bank.

World Bank. (2019, Januari 20). World Bank Database. Dipetik Februari 5, 2019, dari data.worldbank.org: https://data.worldbank.org/ 